\title{
Towards a better understanding of the Organizational Characteristics that affect Acceptance of Big Data Platforms for Academic Teaching
}

\author{
Adnan Aldholay ${ }^{1}$, Osama Isaac ${ }^{2}$, Abdullah Nabeel Jalal ${ }^{3}$, Farah Akmar Anor ${ }^{4}$, Ahmed M. Mutahar ${ }^{5}$ \\ 1,3,4,5 Management and Science University, Selangor, Malaysia \\ ${ }^{2}$ Guangdong University of Finance, Guangdong, China
}

\begin{tabular}{l} 
Article Info \\
\hline Article history: \\
Received Dec 3, 2020 \\
Revised Jul 13, 2021 \\
Accepted Aug 19, 2021 \\
\hline
\end{tabular}

\section{Keyword:}

Big Data

task-technology fit

bandwagon pressure

management drive

training

higher education

\begin{abstract}
In today's era of information, data has been growing at an exponential rate to become big data, and it needs platforms to allow users to govern, access, deliver, analyze, and use these huge databases. Academics in higher education need to utilize these platforms in teaching to enrich and empower the educational experience of their students of these institutions. The purpose of the current study is to investigate the impact of organizational characteristics on the acceptance of big data platforms for academic teaching among higher education institutes in Malaysia. 143 respondents participated to examine the effect of organizational characteristics (Management Drive, Bandwagon Pressure, and Training) on the acceptance of big data platforms for academic teaching. Besides, examining the moderating role of task technology fit. The results illustrate that management drive, bandwagon pressure has a significant impact on acceptance, with an insignificant impact of training on the acceptance. However, task technology fit has not moderated any of the proposed relationships. This study would give insight for the higher education institutes managements to improve their academics acceptance of the big data platforms in teaching and therefore drive them to use the aforementioned platforms.
\end{abstract}

Copyright $@ 2021$ Institute of Advanced Engineering and Science. All rights reserved.

\section{Corresponding Author:}

Adnan Aldholay,

Management and Science University, Selangor, Malaysia

Email: aldholay@msu.edu.my

\section{INTRODUCTION}

Information \& Communication Technology (ICT) has been the main driver in advancing countless activities in human lives to achieve effectiveness (fulfilling goals) and efficiency (optimal resource allocation) [1]. In the higher education context, technology is seen as an indispensable future tool and platform for teaching and learning activities. Nevertheless, the COVID-19 pandemic represented an accelerating factor that made the use of different technological tools in higher education institutions the only option to survive. Among the increasing number of online tools that enhance the quality and delivery of information are big data platforms which is the focus of this study.

Internet as a technology application has allowed information to be accessible at any time and place, as we are approaching the internet of things (IoT) era where billions of devices will be connected and produce a huge amount of data which will be processed and analyzed to extract patterns that present valuable information in every industry, and that is the essence of big data. Nowadays, big data has become a buzzword that immediately draws attention and can be considered the future platform for innovation and productivity [2]. In the context of higher education, big data is expected to enhance this vital sector in the foreseen future, through the function of e-learning, by boosting the students' lecturer interaction, or by facilitating the realization of individual goals and requirements of students [3]; [4].

Studying the acceptance of any technology application involves many factors and perspectives, be it technological, individual, or organizational [5]. Organizational factors will be the focus of this study and how they influence the successful acceptance and adoption of big data platforms in academic teaching. Among these 
factors is management drive which has been examined in different contexts and denotes to the management will facilitate and motivate its employees to embrace specific technology [6,7]. Besides, bandwagon pressure is a phenomenon where other peer organizations influence the actions of their organization [8], and training as an important tool to equip employees with the necessary skills and comprehension of the new technology $[9,10]$. Lastly, this study makes use of the task-technology-fit as a moderating variable as it was found to strengthen the impact in some studies in the literature [11]. This study is opting to promote the use of big data platforms in teaching activities by examining the organizational factors that encourage its use in the context of higher education institutions in Malaysia.

\section{RESEARCH METHOD}

\subsection{Management Drive (MD)}

Management drive is defined as the degree to which the system users have been encouraged and recognized by the top management [12]. While [13] defined it as the degree to which top management provides the system users; useful resources, encouragement, and technical assistance. The explosive developments of technologies in teaching and learning deliveries are making in-depth impacts on today's education industry. Many education providers are experiencing significant transformation and upgrading the arrangement. The traditional working posts become outdated, while new stimuli are opened in bursts. The phenomenon has put forward new challenges for higher education institutions in providing renovated skills and improving the teaching and training methodology that are adaptive to the students as well as trainees [14].

As part of the immense globalization development, higher education now is actively reshaping the institution into a virtual form. The need to enhance virtual education platforms is viewed as a core demand to increase efficiency and capability [15]. However, the correctness of knowledge uploaded in the big data platform is highly discussed among academic practitioners and authorities in ensuring the content is accurate and relevant for academic purposes. To date, big data platforms are imperative in the education setting. Educators used the platform to optimize their tasks in preparing relevant materials as well as effectively engaging with the students. The platform assists educators to diligently prepare relevant teaching modules that fit with a student's capability across their programs. Due to its relevance in acquiring 21 st learning skills for teaching and delivery, the acceptance in using the platform is rather encouraged by the management especially in observing the 21 st learning century [16]. The methodological materials and concepts provided in big data platforms developed imperative and reliable education content which are recommended by the management of higher education as it provides not only the quality education but also the overall atmosphere of the institution [17]. Accordingly, it can be assumed that:

H1: Management drive has a significant impact on the acceptance of big data platforms for academic teaching.

\subsection{Bandwagon Pressure (BP)}

The term bandwagon pressure is given prominence in the literature associated with Big Data, as an organization can be influenced by its competitors to follow suit when it comes to the adoption of new technology. The term bandwagon effect was concocted by $[18,19]$, to highlight the fact that such adoption by an organization, stems from the activity of other organizations [20,21]. This stand is in agreement with that of [22] who used the term herd behavior to describe the bandwagon effect. They opine that the bandwagon effect can serve to reduce the difficulties hampering the acceptance of Big Data, by the educational sector. Given the above, the following hypothesis was conceived to express the influence of the bandwagon pressure effect on the acceptance of Big Data. Accordingly, it can be assumed that:

H2: Bandwagon pressure has a significant impact on the acceptance of big data platforms for academic teaching.

\subsection{Training (TR)}

In the era of a data-driven world, big data is not only important for business but education as well. Big data is an emerging concept, and that is why users of such data and its platforms need to be trained. [23] has defined training as an organized and continued operation, which aims to provide the individual with knowledge, or skill, or ability, or thoughts, or required ideas to perform specific work, or to meet a specific goal. Training has been studied in many aspects and fields and emphasizing its importance in accepting and using big data as a technology. [24] have stressed the importance of training in technology acceptance in the Thai navy context. Furthermore, [25] in their study, suggested that there is a need for training on big data acceptance and usage to improve the utilization of such analytics and platforms in two universities as a context of the study (Technical University of Kenya and Strathmore University in Kenya). In the same line, [26] has stated that business schools and higher education shall evolve to better tackle the educational challenges associated with big data analysis and data science. Likewise, big data analysis impacts the strategy, structure, and organization of companies, it also mutates their processes. Additionally, the smartphone training program among the elderly in the elder university setting confirmed its effectiveness and improved their acceptance and 
usage of such a technology in China [27]. However, based on the aforementioned review, accordingly, it can be assumed that:

H3: Training has a significant impact on the acceptance of big data platforms for academic teaching.

\subsection{Task-Technology Fit (TTF)}

Task-technology fit construct is derived from a theory of the same name that was developed by [28]. It has been extensively used in technology acceptance and adaption in different contexts and is defined as the extent to which a specific technology tool or application supports the user in executing his/her task [29]. Others defined it as the compatibility of the technology with the task [30]. Task-technology fit has known many uses in academic research, as a construct with several measurements [31], and as multiple constructs representing task-technology fit [32], or as an intervening variable whether mediating or moderating [11]. In this study's context as big data platforms represent the technology application under investigation, task-technology fit refers to the compatibility of the aforementioned platforms with the academic staff's task of teaching. Therefore, given the above fundamentals, this study examines the moderating role of task-technology fit in all three relationships in the proposed model as follows:

H4: Task-technology fit to strengthen the positive effect of management drive on acceptance of big data platforms for academic teaching.

H5: Task-technology fit to strengthen the positive effect of bandwagon pressure on acceptance of big data platforms for academic teaching.

H6: Task-technology fit to strengthen the positive effect of training on acceptance of big data platforms for academic teaching.

\subsection{Acceptance of Big Data Platforms for Academic Teaching (ACC)}

The logical flow of actions when studying the use of any new technology application is to identify the factors that will influence, motivate, and prompt an individual to have an intention to use or accept that particular technology which will eventually lead us to study the consequences of that use [33]. Numerous theories in the information system literature have explored this idea such as the theory of reasoned action (TRA) developed by [34], the unified theory of acceptance and use of technology (UTAUT) designed by [35], and technology acceptance model (TAM) constructed by [36]. In this study, acceptance of big data platforms for academic teaching is the main construct of investigation. It refers to the positive perception of academic staff in higher education institutions in Malaysia towards the use of such platforms in their teaching activities. This has become especially important in the era of Covid-19 which accelerated the incorporation of technology in all aspects of education [33]; [37].

\section{RESEARCH METHOD}

\subsection{Conceptual Framework Overview}

The framework below is created based on several concepts and models in the field of information systems that are derived from literature. The role of organizational factors in technology usage and adaption has been seen as crucial to the understanding of new technologies. Management drive, bandwagon pressure, and training are derived from the literature to be elements in the proposed framework. Besides, task technology fit is derived from the model developed by [38]. The model comprises 6 hypotheses to be examined.

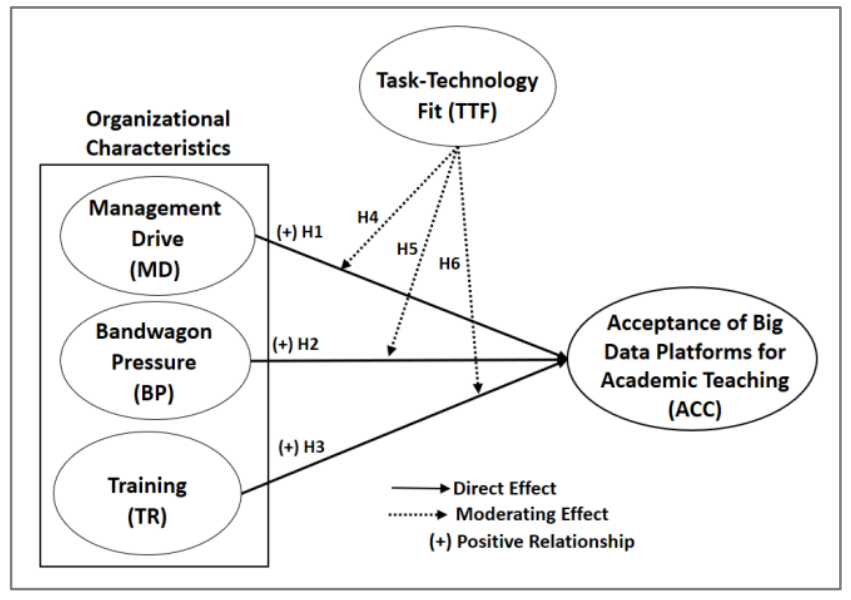

Figure 1. Research model 


\subsection{Development of Instrument and Data collection}

The study utilizes a sample of 143 academic staff in 7 higher education institutions (5 private and 2 public) in Malaysia, using an online-based survey during the period of June-July 2020. The questionnaire adopted a total of 20 items from the literature and incorporated a five-point Likert scale where 1 indicates strongly disagree and 5 indicates strongly agree (refer to Appendix A). Recommendations by [39] were followed in determining the number of items to measure each construct to minimize overlapping.

\section{ANALYSING THE DATA AND RESULTS}

SEM-VB via SmartPLS 3.0 [40] was employed for data analysis and hypothesis testing as suggested by previous research [41]; [42]; [43].

\subsection{Assessment of Measurement Model}

Composite reliability (CR), Cronbach's alpha, The average variance extracted (AVE), and the factor loadings fulfill the requirements [44]; [45] as illustrated in Table 1.

Table 1. Assessment of measurement model

\begin{tabular}{|c|c|c|c|c|c|c|c|}
\hline Constructs & Item & $\begin{array}{l}\text { Loading } \\
(>0.7)\end{array}$ & M & SD & $\begin{array}{c}\alpha \\
(>0.7)\end{array}$ & $\begin{array}{c}\mathrm{CR} \\
(>0.7)\end{array}$ & $\begin{array}{r}\text { AVE } \\
(>0.5)\end{array}$ \\
\hline $\begin{array}{l}\text { Management Drive } \\
\text { (MD) }\end{array}$ & $\begin{array}{l}\text { MD1 } \\
\text { MD2 } \\
\text { MD3 }\end{array}$ & $\begin{array}{l}0.901 \\
0.919 \\
0.936 \\
\end{array}$ & 3.373 & 0.866 & 0.908 & 0.942 & 0.844 \\
\hline $\begin{array}{l}\text { Bandwagon } \\
\text { Pressure } \\
\text { (BP) }\end{array}$ & $\begin{array}{l}\mathrm{BP} 1 \\
\mathrm{BP} 2\end{array}$ & $\begin{array}{l}0.931 \\
0.952\end{array}$ & 3.542 & 0.703 & 0.873 & 0.940 & 0.887 \\
\hline $\begin{array}{c}\text { Training } \\
\text { (TR) }\end{array}$ & $\begin{array}{l}\text { TR1 } \\
\text { TR2 }\end{array}$ & $\begin{array}{l}0.956 \\
0.971\end{array}$ & 2.542 & 1.013 & 0.923 & 0.963 & 0.928 \\
\hline $\begin{array}{c}\text { Task-Technology } \\
\text { Fit (TTF) }\end{array}$ & $\begin{array}{l}\text { TTF1 } \\
\text { TTF2 }\end{array}$ & $\begin{array}{l}0.951 \\
0.964\end{array}$ & 3.359 & 0.809 & 0.910 & 0.957 & 0.917 \\
\hline $\begin{array}{c}\text { Acceptance of Big } \\
\text { Data Platforms for } \\
\text { Academic Teaching } \\
\text { (ACC) }\end{array}$ & $\begin{array}{l}\mathrm{ACC} 1 \\
\mathrm{ACC} 2 \\
\mathrm{ACC} 3\end{array}$ & $\begin{array}{l}0.923 \\
0.977 \\
0.976\end{array}$ & 3.601 & 0.848 & 0.956 & 0.972 & 0.919 \\
\hline
\end{tabular}

Note: $\alpha=$ Cronbach's alpha; $\mathrm{CR}=$ Composite Reliability, $\mathrm{M}=\mathrm{Mean} ; \mathrm{SD}=$ Standard Deviation, $\mathrm{AVE}=$ Average Variance Extracted.

Fornell-Larcker was used to test the discriminant validity, table 2 shows that all constructs of the model were fulfilled satisfactorily [46]; [47]; [48].

Table 2. Fornell-Larcker criterion

\begin{tabular}{|c|c|c|c|c|c|}
\hline & $A C C$ & $B P$ & $M D$ & $T R$ & $T T F$ \\
\hline $\mathrm{ACC}$ & 0.959 & & & & \\
\hline BP & 0.625 & 0.942 & & & \\
\hline MD & 0.539 & 0.514 & 0.919 & & \\
\hline TTF & 0.520 & 0.539 & 0.622 & 0.432 & 0.958 \\
\hline
\end{tabular}

\subsection{Assessment of Structural Model}

According to [48] the structural model can be tested by bootstrapping procedure with a resample of 5,000 , see figure 2 .

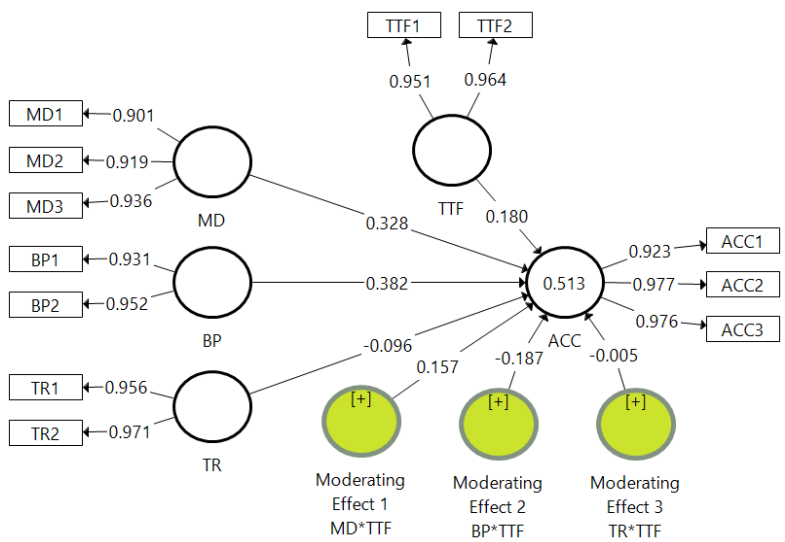

Figure 2. PLS algorithm results 
Note: MD: Management Drive, BP: Bandwagon Pressure, TR: Training, TTF: Task-Technology Fit, ACC: Acceptance of Big Data Platforms for Academic Teaching

\subsubsection{Direct Hypothesis Results}

Table 3 and Figure 2 detail the hypothesis testing results of the structural model. Management drive and bandwagon pressure were identified to positively influence the acceptance of big data platforms in academic teaching. Hence, $\mathrm{H} 1$ and $\mathrm{H} 2$ are accepted with $(\beta=0.328, \mathrm{t}=2.714, \mathrm{p}<0.01)$, and $(\beta=0.382, \mathrm{t}=3.852, \mathrm{p}<0.001)$ respectively, while $\mathrm{H} 3$ is rejected. According to [49] and [50]) the value of 0.51 of $R^{2}$ indicating the explanatory power as an acceptable level.

Table 3. Direct Hypothesis Results

\begin{tabular}{lllllll}
\hline Hypothesis & Relationship & Beta & Std Error & t-value & p-value & Decision \\
\hline H1 & MD $\rightarrow$ ACC & 0.328 & 0.121 & 2.714 & 0.007 & Supported \\
H2 & BP $\rightarrow$ ACC & 0.382 & 0.099 & 3.852 & 0.000 & Supported \\
H3 & TR $\rightarrow$ ACC & -0.096 & 0.089 & 1.083 & 0.279 & Not supported \\
\hline
\end{tabular}

Key: MD: Management Drive, BP: Bandwagon Pressure, TR: Training, TTF: Task-Technology Fit, ACC: Acceptance of Big Data Platforms for Academic Teaching.

\subsubsection{Moderating Effect Hypotheses}

Figure 2 and Table 4 demonstrate that three sub-hypotheses were tested for four main hypotheses which are: (1) Testing the causal effect of a predictor on an outcome, (2) Testing the causal effect of a moderator on an outcome, (3) Testing the causal effect of an interaction (predictor*Moderating) on the outcome. Examining the moderating effect was conducted by testing H4, H5, and H6. This study employed the bootstrapping technique and a resample of 5,000 to evaluate the interaction effect. The results as shown in Table 4 find that $\mathrm{H} 4, \mathrm{H} 5$, and $\mathrm{H} 6$ are rejected.

Table 4. Result of Moderating Effect Hypotheses

\begin{tabular}{cllllll}
\hline Hypothesis & Relationship & Beta & Std Error & t-value & p-value & Decision \\
\hline H9 & MD*TTF $\rightarrow$ ACC & 0.157 & 0.158 & 0.997 & 0.319 & Not supported \\
H1 & BP*TTF $\rightarrow$ ACC & -0.187 & 0.109 & 1.715 & 0.087 & Not supported \\
H12 & TR*TTF $\rightarrow$ ACC & -0.005 & 0.105 & 0.052 & 0.959 & Not supported \\
\hline Key
\end{tabular}

Key: KQ: Knowledge Quality, SEQ: Service Quality, SYQ: System Quality, PE: Perceived Enjoyment, PI: Personal

Innovativeness, ACC: Acceptance of Big Data Platforms for Academic Teaching

\section{DISCUSSION}

The organizational factors' role in influencing the acceptance of big data platforms in academic teaching was examined in this study, as such, management drive was found to significantly influence the acceptance of big data platforms. That is, employees tend to have stronger acceptance of big data platforms when the management of their institution considers big data platforms as important to enhance learning outcome, effectively communicates its support for the use of big data platforms in teaching, and have established standards to utilize big data platforms as a performance indicator. This finding is in line with previous studies that examined the role of management support and found it to be significant in different settings and contexts [5,7,51]. Further, the study found a significant impact of bandwagon pressure on the acceptance of big data platforms, it can be understood by the notion that employees' acceptance of big data platforms is enhanced when more of their peers in other higher education organizations use big data platforms in teaching and are typically active with big data platforms. This result adds to the existing literature on the bandwagon pressure role $[8,52,53]$.

Further, training was found to not have a significant impact on the acceptance of big data platforms in academic teaching. This can be explained by the assumption that employees nowadays are equipped with minimum skills to interact with basic technology and thus having training in the context of big data platforms does not affect their acceptance of that technology.

Moreover, unlike studies that used task-technology-fit as a moderating variable and found it to be significant [11]. This study found task-technology-fit does not strengthen nor dampen the effect of each of management drive, bandwagon pressure, and training on the acceptance of big data platforms in academic teaching. We can view such findings from the perspective that the first two relationships are already strong in the era of covid-19 where higher education managements have resorted to the only option to keep the educational process running through online learning with numerous platforms that are being used by all academic staff, therefore, they are used to such technological tools in teaching during lockdowns and are likely to accept another tool such as big data platforms. As for the last relationship which is training on the acceptance 
of big data and since it was not significant, thus there can not be a moderating effect of task-technology-fit on that relationship [54].

\section{IMPLICATIONS}

The significant goal of this study is to scrutinize the organizational characteristics that affect the acceptance of Big Data platforms in an educational context. The current research supports the crucial role of Big Data in educational organizations and will assist online educators and learners to fully realize the importance of Big Data platforms. The findings of this study might assist educational organizations to develop successful platforms through big data activities by crafting policies and guidelines to institutionalize the employment of big data capabilities in the teaching and learning process through training, motivation, and evaluation. This study contributes to the Big Data literature in different ways. First, the study develops promising information on the antecedents and outcomes of the organizational characteristics. Followed by the concurrent effect of management drive, and bandwagon pressure towards the acceptance of big data platforms. Lastly, the study has conceptualized a comprehensive acceptance framework which, therefore, can be considered as a guideline to most practitioners who tend to implement and utilize Big Data platforms.

\section{CONCLUSION}

With the emergence of Big Data platforms, higher education organizations seemed to have significant challenges in motivating their academicians to accept and adopt those platforms. Moreover, the lack of a contextual adoption model that can lead to a successful implementation of big data in the higher education context has played a key role in detaining the benefits of such advancement in education. This study has bridged the gap of the existing literature with a comprehensive model that conceptualized influential organizational characteristics/factors that affect the acceptance of Big Data platforms in the academic field. The relationships were critically interpreted with levels of significance and impact on acceptance. Consequently, this study has a significant contribution and guidelines for most educational institutions facing misleading information on the acceptance of big data adoption. Few limitations to this study, namely the data collected were at one point which might differ or change over time due to different situations. The study examined the impact of management drive, bandwagon pressure, and training on the acceptance of big data platforms in academic teaching, besides examining the moderation role of task-technology fit on all relationships. The major highlight of this study is the importance of management intention and drive to push for the adaption of big data platforms in the teaching and learning activities.

\section{ACKNOWLEDGEMENTS}

This study was sponsored by the Management and Science University under seed grant number (SG20190527017-FBMP) for the year 2020 .

\section{APPENDIX}

\begin{tabular}{|c|c|c|}
\hline Variable & Measure & Source \\
\hline $\begin{array}{l}\text { Management } \\
\text { Drive } \\
\text { (MD) }\end{array}$ & $\begin{array}{l}\text { MD1: Management considers big data platforms as important to enhance learning } \\
\text { outcomes. } \\
\text { MD2: Management effectively communicates its support for the use of big data } \\
\text { platforms in teaching. } \\
\text { MD3: Management has established standards to utilize big data platforms as a } \\
\text { performance indicator. }\end{array}$ & [55] \\
\hline $\begin{array}{l}\text { Bandwagon } \\
\text { Pressure } \\
\text { (BP) }\end{array}$ & $\begin{array}{l}\text { BP1: Most higher education organizations use big data platforms in teaching. } \\
\text { BP2: Educational organizations in surrounding locations typically are active with big } \\
\text { data platforms. }\end{array}$ & [53] \\
\hline $\begin{array}{l}\text { Training } \\
\text { (TR) }\end{array}$ & $\begin{array}{l}\text { TR1: My organization provided me an adequate training on how to use big data } \\
\text { platforms. } \\
\text { TR2: My organization provided me a complete training on how to use Big data } \\
\text { platforms. }\end{array}$ & [56] \\
\hline $\begin{array}{l}\text { Task-Technology } \\
\text { Fit } \\
\text { (TTF) }\end{array}$ & $\begin{array}{l}\text { TTF1: Big data platforms fit with the way I like to teach. } \\
\text { TTF2: Big data platforms are suitable for helping me complete my academic } \\
\text { performance. }\end{array}$ & [57] \\
\hline $\begin{array}{l}\text { Acceptance of Big } \\
\text { Data Platforms } \\
\text { (ACC) }\end{array}$ & $\begin{array}{l}\text { ACC1: Assuming that I had access to the big data platforms I intend to use it. } \\
\text { ACC2: I am planning to use big data platforms now and in the future. } \\
\text { ACC3: I will strongly recommend others to use big data platforms in teaching. }\end{array}$ & $\begin{array}{c}\text { (Lee \& Lehto, 2013)[59] } \\
{[60]}\end{array}$ \\
\hline
\end{tabular}

\section{REFERENCES}

[1] Ali O, Shrestha A, Osmanaj V, Muhammed S. Cloud computing technology adoption: an evaluation of key factors in local governments. Inf Technol People. 2020; 
[2] Sedkaoui S, Khelfaoui M. Understand, develop and enhance the learning process with big data. Inf Discov Deliv. 2019;47(1):2-16.

[3] Md Talib Z, Mosbah A, Al-Jubari I. Intention to Pursue Postgraduate Studies in Malaysian Universities. Int J Innov Creat Chang. 2019 Aug 28;5(2):591-609.

[4] Md Talib Z, Mosbah A, Al-Jubari I. Intention to Pursue Postgraduate Studies in Malaysian Universities. Int J Innov Creat Chang. 2019 Aug 28;5(2):591-609.

[5] Barham H, Dabic M, Daim T, Shifrer D. The role of management support for the implementation of open innovation practices in firms. Technol Soc [Internet]. 2020;63(June):101282. Available from: https://doi.org/10.1016/j.techsoc.2020.101282

[6] Clohessy T, Acton T. Investigating the influence of organizational factors on blockchain adoption: An innovation theory perspective. Ind Manag Data Syst. 2019;119(7):1457-91.

[7] Liu J, Liu Y, Yang L. Uncovering the influence mechanism between top management support and green procurement: The effect of green training. J Clean Prod [Internet]. 2020;251:119674. Available from: https://doi.org/10.1016/i.jclepro.2019.119674

[8] Waddell TF, Sundar SS. Bandwagon effects in social television: How audience metrics related to size and opinion affect the enjoyment of digital media. Comput Human Behav [Internet]. 2020;107(January):106270. Available from: https://doi.org/10.1016/i.chb.2020.106270

[9] Shigenobu K, Ikeda M. EFFECTS OF TRAINING ON EMPLOYEE PERFORMANCE. Evidence. Brain and Nerve [Internet]. 2013;61(11):1337-42. Available from: https://core.ac.uk/download/pdf/38098025.pdf

[10] Nzeru W, Nzimakwe I, Mutambara E, Munapo E. Impact of Training and Development on Employees' Performance. Indian Econ J. 2015;63(3):448-72.

[11] Chang C-C. Library mobile applications in university libraries. Libr Hi Tech. 2013;31(3):478-92.

[12] Son H, Park Y, Kim C, Chou J-S. Toward an understanding of construction professionals' acceptance of mobile computing devices in South Korea: An extension of the technology acceptance model. Autom Constr. 2012 Dec;28:82-90.

[13] Lee Y-H, Hsieh Y-C, Ma C-Y. A model of organizational employees' e-learning systems acceptance. KnowledgeBased Syst. 2011 Apr;24(3):355-66.

[14] Zhang N. A Campus Big-Data Platform Architecture for Data Mining and Business Intelligence in Education Institutes. 2016.

[15] Yoo DK. Perceived knowledge quality: A sensemaking perspective. 18th Am Conf Inf Syst 2012, AMCIS 2012. 2012;4:2572-9.

[16] Saavedra AR, Opfer VD. Learning 21st-Century Skills Requires 21st-Century Teaching. Phi Delta Kappan [Internet]. 2012 Oct 1;94(2):8-13. Available from: https://doi.org/10.1177/003172171209400203

[17] Agariya A, Singh D. E-Learning quality: Scale development and validation in Indian context. Knowl Manag ELearning. 2012 Dec 1;4:500-17.

[18] Yoon TE, George JF. Why aren’t organizations adopting virtual worlds? Comput Human Behav. 2013;29(3):772_ 790.

[19] Sinclaire J, Vogus C. Adoption of Social Networking Sites: An Exploratory Adaptive Structuration Perspective for Global Organizations. Inf Technol Manag. 2011 Dec 1;12:293-314.

[20] Jalal AN, Bahari M, Tarofder AK, Musa WMNMW. Factors influencing customer social relationship management implementation and its benefits in healthcare industry. Polish J Manag Stud. 2019;19(2):196-205.

[21] Jalal AN, Bahari M, Musa MW, Sherief SR. Social media and traditional customer relationship management: An overview of theoretical challenges and future directions in healthcare context. Int J Adv Trends Comput Sci Eng. 2019;8(1.6 Speciallssue):76-82.

[22] Parameswaran M, Whinston A. Research issues in social computing. J Assoc Inf Syst. 2007;8(6).

[23] Abdelwahab A. individual's management: analytic method to organization and management and people. Ain Shams University, Cairo; 1975

[24] Vathanophas V, Krittayaphongphun N, Klomsiri C. Technology acceptance toward e-government initiative in Royal Thai Navy. Transform Gov People, Process Policy. 2008;2(4):256-82.

[25] Kibe LW, Kwanya T, Owano A. Relationship between big data analytics and organisational performance of the Technical University of Kenya and Strathmore University in Kenya. Glob Knowledge, Mem Commun. 2020;69(67):537-56.

[26] Carillo KDA. Let's stop trying to be "sexy" - preparing managers for the (big) data-driven business era. Bus Process Manag J. 2017;23(3):598-622.

[27] Zhao X, Wang L, Ge C, Zhen X, Chen Z, Wang J, et al. Smartphone application training program improves smartphone usage competency and quality of life among the elderly in an elder university in China: A randomized controlled trial. Int J Med Inform. 2020;133(May 2019):104010.

[28] Goodhue DL, Thompson RL. Task-Technology Fit and Individual Performance. MIS Q. 1995;19(2):213-36.

[29] Isaac O, Aldholay A, Abdullah Z, Ramayah T. Online learning usage within Yemeni higher education : The role of compatibility and task-technology fit as mediating variables in the IS success model. Comput Educ [Internet]. 2019;136(November 2017):113-29. Available from: https://doi.org/10.1016/i.compedu.2019.02.012

[30] Ratna S. Characteristics of tasks and technology as a driver of task-technology fi t and the use of the hotel reservation information system. 2018;48(4):579-95. 
[31] Ullah I, Hameed Z, Yu Y, Islam T, Sheikh Z. Predicting the acceptance of MOOCs in a developing country: Application of task-technology fi t model, social motivation, and self-determination theory. Telemat Informatics [Internet]. 2018;35(4):964-78. Available from: https://doi.org/10.1016/j.tele.2017.09.009

[32] Li Y, Yang S, Zhang S, Zhang W. Mobile social media use intention in emergencies among Gen Y in China : An integrative framework of gratifications, task-technology fit, and media dependency. Telemat Informatics [Internet]. 2019;42(January):101244. Available from: https://doi.org/10.1016/j.tele.2019.101244

[33] Cabrera-Sánchez JP, Villarejo-Ramos ÁF. Acceptance and use of big data techniques in services companies. J Retail

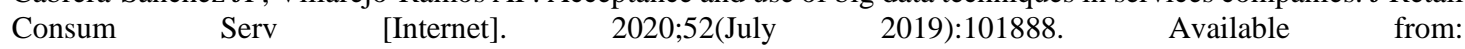
https://doi.org/10.1016/j.jretconser.2019.101888

[34] Fishbein M. Reasoned Action, Theory of [Internet]. The International Encyclopedia of Communication. 2008. (Major Reference Works). Available from: https://doi.org/10.1002/9781405186407.wbiecr017

[35] Venkatesh V, Thong JYL, Chan FKY, Hu PJ-H, Brown S a. Extending the two-stage information systems continuance model: incorporating UTAUT predictors and the role of context. Inf Syst J. 2011 Nov;21(6):527-55.

[36] Davis FD. Perceived Usefulness , Perceived Ease Of Use , And User Acceptance. MIS Q. 1989;13(3):319-39.

[37] Purwanto E, Mutahar AM. Examine the Technology of Acceptance Model Among Mobile Banking Users in Indonesia. Technol Reports Kansai Univ. 2020;62(07):3969-79.

[38] Goodhue, Dale L, Thompson, Ronald L. Task-technology fit and individual performance. MIS Q. 1995;19(2):21336.

[39] A Hayduk L, Littvay L. Should researchers use single indicators, best indicators, or multiple indicators in structural equation models? BMC Med Res Methodol. 2012;12(1):159.

[40] Ringle CM, Wende S, Becker J-M. SmartPLS 3. Bonningstedt: SmartPLS. 2015.

[41] Isaac O, Abdullah Z, Aldholay AH, Abdulbaqi Ameen A. Antecedents and outcomes of internet usage within organisations in Yemen: An extension of the Unified Theory of Acceptance and Use of Technology (UTAUT) model. Asia Pacific Manag Rev [Internet]. 2019;24(4):335-54. Available from: https://doi.org/10.1016/j.apmrv.2018.12.003

[42] Isaac O, Abdullah Z, Ramayah T, Mutahar AM. Internet usage , user satisfaction , task-technology fit , and performance impact among public sector employees in Yemen. Int J Inf Learn Technol. 2017;34(3):210-41.

[43] Purwanto E, Deviny J, Mutahar AM. The Mediating Role of Trust in the Relationship between Corporate Image, Security, Word of Mouth and Loyalty in M-Banking Using among the Millennial Generation in Indonesia. Manag Mark. 2020;15(2):255-74.

[44] Kline RB. Principles and practice of structural equation modeling. 3rd ed. New York: The Guilford Press; 2010.

[45] Hair JF, Black WC, Babin BJ, Anderson RE. Multivariate Data Analysis. 7th ed. New Jersey: Pearson; 2010.

[46] Fornell C, Larcker DF. Evaluating structural equation models with unobservable variables and measurement error. J Mark Res. 1981;18(1):39-50.

[47] Chin WW. The partial least squares approach to structural equation modeling. In G. A. Marcoulides (Ed.), Modern methods for business research (pp. 295-358). New Jersey: Lawrence Erlbaum Associates. Mahwah, NJ: Lawrence Erlbaum; 1998.

[48] Hair JF, Hult GTM, Ringle C, Sarstedt M. A Primer on Partial Least Squares Structural Equation Modeling (PLSSEM). 2nd ed. London: Thousand Oaks: SAGE.; 2017.

[49] Chin WW. Issues and opinion on structural equation modeling. MIS Q. 1998;22(1):7-16.

[50] Cohen J. Statistical Power Analysis for the Behavioral Sciences. Second Ed. New York: Routledge; 1988. 400 p.

[51] Kanwal N, Zafar MS, Bashir S. The combined effects of managerial control, resource commitment, and top management support on the successful delivery of information systems projects. Int $\mathrm{J}$ Proj Manag [Internet]. 2017;35(8):1459-65. Available from: https://doi.org/10.1016/j.ijproman.2017.08.007

[52] Mainolfi G. Exploring materialistic bandwagon behaviour in online fashion consumption: A survey of Chinese luxury consumers. J Bus Res [Internet]. 2019;(September 2018):1-8. Available from: https://doi.org/10.1016/j.jbusres.2019.11.038

[53] Kim J, Gambino A. Do we trust the crowd or information system? Effects of personalization and bandwagon cues on users' attitudes and behavioral intentions toward a restaurant recommendation website. Comput Human Behav [Internet]. 2016;65:369-79. Available from: http://dx.doi.org/10.1016/j.chb.2016.08.038

[54] Hayes A. Introduction to Mediation, Moderation, \& Conditional Process Analysis. First. The Guilford Press; 2013. $507 \mathrm{p}$.

[55] Premkumar G, Ramamurthy K. The Role of Interorganizational and Organizational Factors on the Decision Mode for Adoption of Interorganizational Systems*. Decis Sci [Internet]. 2007 May 1;26(3):303-36. Available from: https://doi.org/10.1111/j.1540-5915.1995.tb01431.x

[56] Compeau DR, Higgins C a. Application of Social Cognitive Theory to Training for Computer Skills. Inf Syst Res. 1995 Jun;6(2):118-43.

[57] Irick ML. Task-Technology Fit and Information Systems Effectiveness. J Knowl Manag Pract. 2008;9(3).

[58] Lee DY, Lehto MR. User acceptance of YouTube for procedural learning: An extension of the Technology Acceptance Model. Comput Educ. 2013;61(1):193-208.

[59] Ong C-S, Lai J-Y. Gender differences in perceptions and relationships among dominants of e-learning acceptance. Comput Human Behav. 2006 Sep;22(5):816-29.

[60] Alrajawy I, Daud NM, Isaac O, Mutahar AM. Examine Factors Influencing the Intention to use Mobile Learning in Yemen Public Universities. Asian J Inf Technol. 2017;16(2):287-97. 